\title{
The North Atlantic Oscillation and sea surface temperature affect loggerhead abundance around the Strait of Gibraltar
}

\author{
JOSÉ C. BÁEZ ${ }^{1,2}$, JUAN J. BELLIDO ${ }^{2,3}$, FRANCISCO FERRI-YÁÑEZ ${ }^{2,4}$, \\ JUAN J. CASTILLO ${ }^{3}$, JUAN J. MARTÍN ${ }^{3}$, JOSÉ L. MONS ${ }^{3}$, DAVID ROMERO ${ }^{2}$ \\ and RAIMUNDO REAL ${ }^{2}$ \\ ${ }^{1}$ Instituto Español de Oceanografia (IEO), Centro Oceanográfico de Málaga, Puerto pesquero de Fuengirola s/n, E-29640, \\ Málaga, Spain. E-mail: jcarlos.baez@ma.ieo.es \\ ${ }_{2}^{2}$ Departamento de Biología Animal, Facultad de Ciencias, Universidad de Málaga. E-29071, Málaga, Spain. \\ ${ }_{3}^{3}$ Aula del Mar de Málaga. Avda. M. Heredia 35, E-29001, Málaga, Spain. \\ ${ }^{4}$ Consejo Superior de Investigaciones Científicas, Museo Nacional de Ciencias Naturales, 28006, Madrid, Spain.
}

\begin{abstract}
SUMMARY: The aim of this study was to explore the possible link between variations in the North Atlantic Oscillation (NAO) and sea surface temperature (SST) and the abundance of loggerhead turtles around the Strait of Gibraltar, using stranding data for the Andalusian coastal area as a proxy for abundance. The annual average SST (from November to October) in the Gulf of Cadiz was negatively associated with the total number of loggerhead strandings each year from November 1997 to October 2006 in the Gulf of Cadiz and the Alboran Sea. The average NAO index was positively associated with the number of strandings in the Gulf of Cadiz in the following year. Prevailing westerly winds during positive NAO phases and the subsequent delayed decrease in SST may lead to turtles from the west Atlantic accumulating in the Gulf of Cadiz and unsuccessfully attempting to return. Secondary causes, such as buoyancy, cold stunning, longline fisheries, net fisheries, debilitated turtle syndrome, and trauma may also increase the number of turtle strandings.
\end{abstract}

Keywords: global change, Gulf of Cadiz, marine migratory species, Mediterranean Sea, sea turtle.

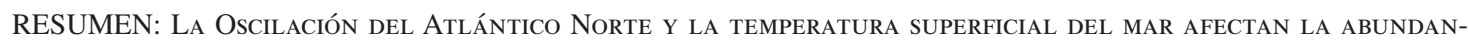
CIA DE LA TORTUga boba ALREDEDOR DEl estrecho de Gibraltar. - El objetivo de este estudio fue explorar la posible relación entre las variaciones de la Oscilación del Atlántico Norte (NAO) y la temperatura superficial del mar (SST), y la abundancia de tortugas bobas alrededor del Estrecho de Gibraltar, utilizando los datos de varamientos como sustituto de la abundancia. La SST promedio en el Golfo de Cádiz se relacionó negativamente con el número total de tortugas bobas varadas durante cada año (de noviembre a octubre) desde 1997 hasta 2006 en el Golfo de Cádiz y en el Mar de Alborán, mientras que el promedio del índice NAO se relacionó positivamente con el número de varamientos en el Golfo de Cádiz durante el año siguiente. Vientos predominantes del oeste durante las fases de la NAO positiva, y su posterior retraso en la reducción de la SST, pueden provocar la acumulación en el Golfo de Cádiz de las tortugas que entran desde el Atlántico occidental y, las que sin éxito, tratan de regresar a sus playas de origen. Debido a causas secundarias (como problemas de flotabilitdad, enfriamiento, la pesca con palangre, la pesca con redes, DTS, y traumatismos) aumenta el número de tortugas varadas.

Palabras clave: cambio global, especies marinas migradoras, golfo de Cádiz, mar Mediterráneo, tortugas marinas.

\section{INTRODUCTION}

The loggerhead turtle Caretta caretta is an important migratory species included in the IUCN red list of threatened species (http://www.redlist.org/). Its physi- ology and behaviour is affected by variations in sea surface temperature (SST) and wind patterns (Bellido et al., 2008; Schofield et al., 2009). Several authors have raised the issue of whether climate change may affect turtle populations by reducing the number of 
hatchlings, altering the normal sex ratio (Hawkes et al., 2007b; Witt et al., 2010) and decreasing neonatal survival (McCallum et al., 2009). Recent evidence suggests that changes in climatic conditions are responsible for a documented shift in the reproductive season of western North Atlantic loggerheads because oviposition now occurs earlier (Weishampel et al., 2004). Climate change may also cause profound alterations in migratory routes and resource availability (Robinson et al., 2008).

In this context, several authors have hypothesized that marine migratory species may respond to climatic conditions by altering their migratory phenology (Chaloupka et al., 2008a; Mazaris et al., 2008) and their local abundance, although this has rarely been demonstrated. It has been suggested that the North Atlantic Oscillation (NAO) in particular may have an effect on the distribution and recruitment of several migratory species (e.g. see Sims et al., 2001; Goñi and Arrizabalaga, 2005; Gancedo et al., 2009; Graham and Harrold, 2009). The NAO reflects fluctuations in atmospheric pressure at sea level between the Icelandic Low and the Azores High. The NAO is associated with many meteorological variations in the North Atlantic region, affecting wind speed and direction and differences in temperature and rainfall. The potential effect of the NAO on loggerhead abundance patterns has not yet been analysed.

The Gulf of Cadiz and the Alboran Sea form part of the northern tip of the Eastern Boundary Current System of West Europe and North Africa. In this marine area regional-scale processes are marked by the seasonal alternation of downwelling water masses (in winter) and upwelling water masses (in summer), which alter the SST. Sánchez et al. (2007) showed that a regional-scale pattern that fluctuates between a cyclonic and an anticyclonic mode in the Gulf of Cadiz is associated with coupled wind-SST variability driven by the NAO. The SST, in turn, has been shown to affect local loggerhead abundance patterns (e.g. Watson et al., 2005; Hawkes et al., 2007a).

Many authors have found an association between the number of strandings recorded on the coast and the abundance of loggerhead turtles in the sea (Camiñas and de la Serna, 1995; Epperly et al., 1996; Tomás et al., 2008; Bellido et al., 2010). In this context, the local time series of turtle strandings may be a useful proxy for estimating trends in the abundance of marine turtles (MacLeod et al., 2004; Witt et al., 2007; Chaloupka et al., 2008b). Annually, hundreds of loggerheads, born on beaches in the North Atlantic Ocean (Eckert et al., 2008; Monzon-Arguello et al., 2010), strand along the southern Iberian Peninsula on their way to their feeding grounds in the western Mediterranean Sea or while they are returning to their natal regions (Bellido et al., 2010).

The aim of this study was to explore the possible link between variations in the NAO and SST and the abundance of loggerheads around the Strait of Gibral-

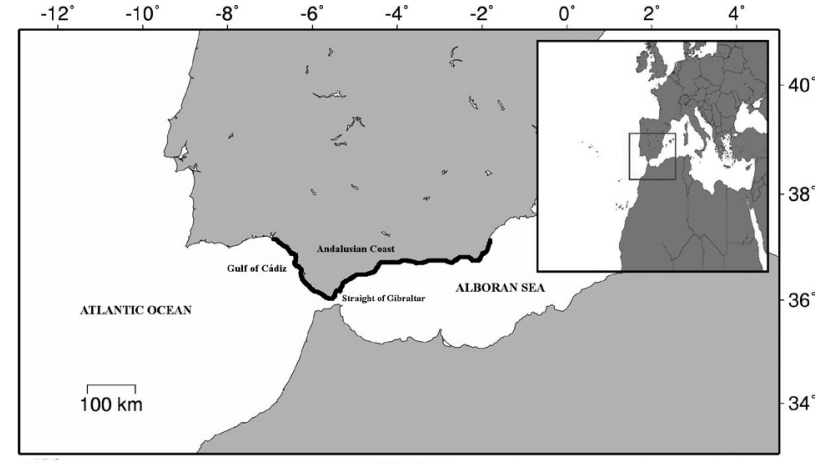

FIG 1. - The Andalusian coast, showing two regions: the Gulf of Cadiz (in the Atlantic Ocean) and the Alboran Sea (within the Mediterranean Sea).

tar, using stranding data for the southern coasts of the Iberian Peninsula.

\section{MATERIALS AND METHODS}

The study area was the Andalusian coast, which comprises $1100 \mathrm{~km}$ of coastline extending from $37^{\circ} 10^{\prime} \mathrm{N}, 7^{\circ} 23^{\prime} \mathrm{W}$ to $37^{\circ} 22^{\prime} \mathrm{N}, 1^{\circ} 37^{\prime} \mathrm{W}$. The Strait of Gibraltar divides the Andalusian coast into two parts, the Gulf of Cadiz (Atlantic) and the Alboran Sea (Mediterranean) (Fig. 1). Loggerhead stranding data was systematically recorded along the Spanish coasts of the Gulf of Cadiz and the Alboran Sea from 1997 to 2006 by the Threatened Marine Species Recovery Centre of Andalusia (abbreviated as CREMA in Spanish), and a large network of volunteers covering the entire Andalusian coast. Local police and scientific groups also collaborated in detecting stranded turtles. As Andalusian beaches are used intensively it is unlikely that an animal stranded on the beach would go unnoticed.

Whenever possible, the cause of the stranding was identified by necropsy and live animal diagnostics. The causes of stranding were diverse and most strandings were due to buoyancy, cold stunning, longline fisheries, net fisheries, trauma and debilitated turtle syndrome (DTS) (Bellido et al., 2010). We followed the definition of DTS provided by Day et al. (2010): "debilitated turtles are characterized by emaciation and heavy burdens of external and internal parasites, and bacterial infections, but the underlying cause of their condition is unknown".

Monthly NAO index values were taken from the website of the National Oceanic and Atmospheric Administration:

http://www.cpc.noaa.gov/products/precip/CWlink/ pna/nao_index.html

The NAO shows strong inter-annual and intraannual variability (Hurrell 1995; Peng et al. 2002), and there is only a strong NAO pattern in winter, primarily from November to April. However, several studies have shown that changes in NAO trends have a delayed effect on aquatic ecosystems due to ecosystem inertia. Some examples of these effects are the marked 
increase in water levels in Iberian rivers (Trigo et al., 2004), as well as changes in the breeding periodicity of the Common Eider Somateria mollissima (D'Alba et al., 2010). Thus, we compared the number of loggerhead strandings between November and October in our study region with the average NAO index during the "NAO cycle" between November and October prior to the year of stranding (NAOpy hereafter).

Monthly SST averages for each area (Gulf of Cadiz [SST_GC] and the Alboran Sea [SST_AS]) were extracted from the Extended Reconstruction Sea Surface Temperature (ERSST.v3b) dataset, freely available from the National Oceanic and Atmospheric Administration (NOAA, http://www.noaa.gov).

Linear multiple regressions were used to test the monotonic responses of the total number of stranded loggerheads (frequency of stranded loggerheads in the Gulf of Cadiz [Nstranded GC]; frequency of stranded loggerheads in the Alboran Sea [Nstranded AS]) to the NAOpy and SST. We used the stepwise regression method for objective variable selection. The data were tested for normality using the Kolmogorov-Smirnov test.

\section{RESULTS}

There was an annual average of 126 turtle strandings, with a peak between October 2000 and November 2001 (331 turtle strandings) and a trough between October 1998 and November 1999 (38 turtle strandings; standard deviation=84.82). Seventy-eight per cent of the turtles were dead at the time of stranding, and 22\% of turtles were found alive. More information on loggerhead stranding data can be found in Bellido et al. (2010).

The NAO was in a positive phase for 4 years of the study period, and in a negative phase during the other 5 years. A significant association was found between the total number of loggerhead strandings in the Gulf of Cadiz and the NAOpy index and SST according to the following function (Fig. 2):

$$
\begin{aligned}
\text { Nstranded } \mathrm{GC}= & 3035.3023+62.07201 \mathrm{NAOpy}- \\
& 156.439 \mathrm{SST}+\mathrm{GC} \\
\text { (adjusted } \mathrm{R}^{2}= & 0.855 ; \mathrm{F}=24.532 ; \mathrm{P}=0.00129) .
\end{aligned}
$$

$($ NAOpy $\beta$-value $=0.5902 ;$ SST_GC $\beta$-value $=-0.564)$.

There were no statistically significant correlations between the independent variables.

The number of loggerhead strandings in the Alboran Sea had a significant negative relationship with SST_GC according to the following function (Fig. 3):

Nstranded AS $=6181.643-322.997$ SST_GC (adjusted $\mathrm{R}^{2}=0.6704 ; \mathrm{F}=17.271 ; \mathrm{P}=0.00426$ ). (SST_GC $\beta$-value $=-0.844)$.

However, no significant associations were found between the NAO and the total number of loggerhead strandings in the Alboran Sea.
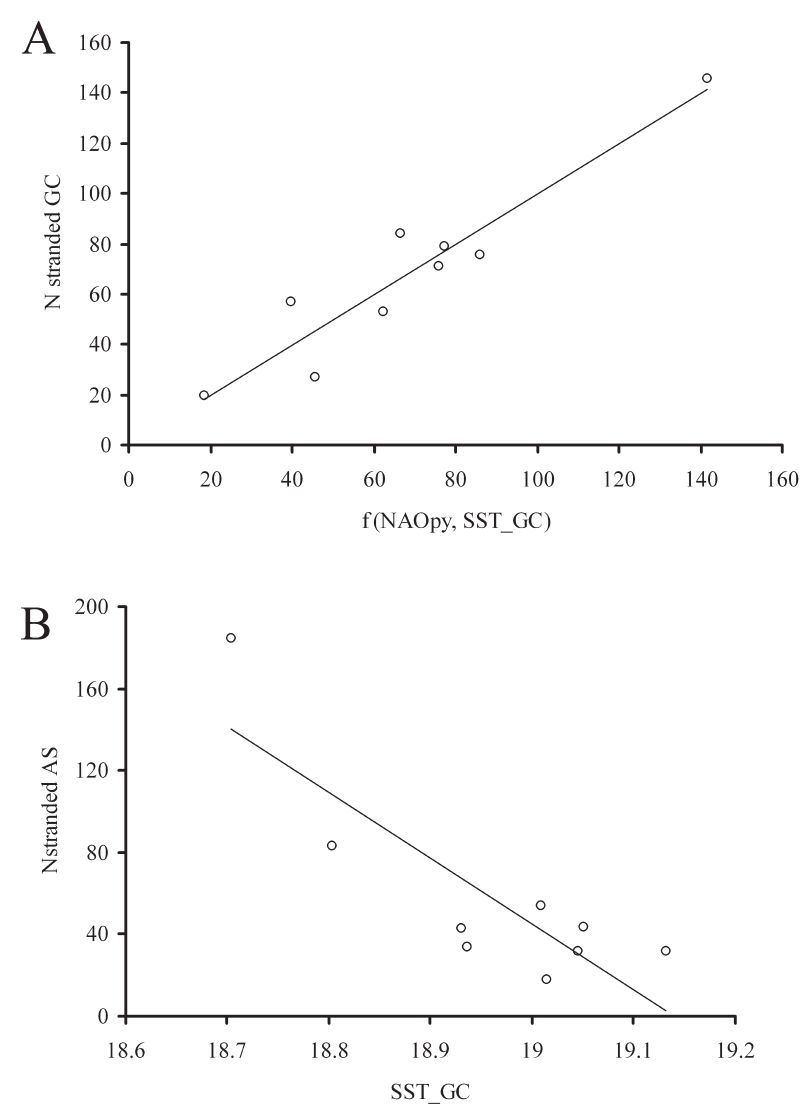

FIG 2. - Linear response of loggerhead strandings as a function of the explanatory variables from 1997 to 2006: A) Linear response of the total number of loggerhead strandings in the Gulf of Cadiz as a function of the average SST in the Gulf of Cadiz between November and October, and the average NAO index between November and October of the year prior to that of the stranding; B) Linear response of the total number of loggerhead strandings in the Alboran Sea to the average SST in the Gulf of Cadiz between November and October.

\section{DISCUSSION}

The association between the NAO and loggerhead abundance around the Strait of Gibraltar could be due to the relationship of the NAO to wind and temperature patterns. As Visbeck et al. (2001) reported, a positive NAO phase results in stronger-than-average westerly winds across northern mid-latitudes, which affects both marine and terrestrial ecosystems. These prevailing westerlies could benefit immature turtles born on American beaches that are attempting to reach the Mediterranean feeding areas; however, they could be detrimental to loggerheads returning to nesting areas in the western North Atlantic. This would lead to loggerheads accumulating around the Strait of Gibraltar, which is both the receiving area for newcomers and the starting point for returning loggerheads. Therefore, the probability of a loggerhead stranding due to causes that are unrelated to the NAO (such as buoyancy, cold stunning, longline fisheries, net fisheries, DTS and trauma) would also increase. In addition, the SST is also affected during a positive NAO phase, with a cold 
subtropical anomaly between the equator and $30^{\circ} \mathrm{N}$ (an area crossed by tagged adult loggerheads travelling to nesting beaches (e.g. see Eckert et al., 2008)), which also makes the journey back to natal beaches difficult.

A striking feature of our results is that the total number of loggerhead strandings in the Alboran Sea was significantly associated with the SST in the Gulf of Cadiz rather than the SST in the Alboran Sea. This could be due to the cold sea temperature in the Gulf of Cadiz, which hinders subadult loggerheads returning to their natal regions. This increases the concentration of loggerheads not only in the Gulf of Cadiz but also around the Strait of Gibraltar, and many loggerheads cross the strait back into the Alboran Sea either voluntarily or due to the prevailing current.

This hypothesis is supported by the results provided by Bellido et al. (2010), who found that loggerheads stranded in the Gulf of Cadiz were larger than those stranded in the Alboran Sea, which suggests that adults and larger juveniles preparing to migrate to the breeding grounds concentrate in the Gulf of Cadiz. Using Argos satellite-tag data, Eckert et al. (2008) analysed the movement pathways of 15 juvenile and subadult loggerhead turtles tagged in the western Mediterranean Sea, and demonstrated that around the Alboran Sea individual variations in loggerhead distribution were partially size dependent. Eckert et al. (2008) suggested that the western Alboran Sea is a staging area for larger western Atlantic juveniles preparing to return to their breeding grounds in western Atlantic coastal areas. Although subadult loggerheads leaving the Mediterranean Sea are not as dependent on environmental conditions as they were when they were smaller juveniles, migration from east to west is active rather than passive, and may be affected by winds and temperatures. Consequently, when the conditions are inappropriate for migration, loggerhead abundance increases both in the Gulf of Cadiz and the Alboran Sea.

The incidence of strandings in the Gulf of Cadiz was found to mainly depend on two climatic variables, one of which (NAOpy) can be determined 1 year in advance. Therefore, it is possible to partially forecast annual abundance patterns, which could have important applications in conservation strategies and for allocating resources for the management of the species.

\section{ACKNOWLEDGEMENTS}

We are grateful to the Consejería de Medio Ambiente de la Junta de Andalucía for providing data on strandings. We would also like to thank the two anonymous referees for their comments. This study was partially funded by the project CGL2009-11316 (Ministerio de Ciencia e Innovación, Spain, and FEDER).

\section{REFERENCES}

Bellido, J.J., J.C. Báez, J.J. Castillo, F. Pinto, J.J. Martín, J.L. Mons and R. Real. - 2008. Mass strandings of cold-stunned loggerhead turtles in the south Iberian Peninsula: ethological implica- tions. Ethol. Ecol. Evol, 20: 401-405.

Bellido, J.J., J.J. Castillo, F. Pinto, J.J. Martín, J.L. Mons, J.C. Báez and R. Real. - 2010. Differential geographical trends for loggerhead turtles stranding dead or alive along the Andalusian coast, southern Spain. J. Mar. Biol. Assoc. UK., 90: 225-231.

Camiñas, J.A. and J.M. de la Serna. - 1995. The loggerhead distribution in the western Mediterranean Sea as deduced from captures by the Spanish longline fishery. In: G.A. Llorente, A. Montori, X. Santos and M.A. Carretero, (eds.). Sci. Herpet., 316-323.

Chaloupka, M., T.M. Work, G.H. Balazs, S.K.K. Murakawa and R. Morris. - 2008a. Cause-specific temporal and spatial trends in green sea turtle strandings in the Hawaiian Archipelago (19822003). Mar. Biol., 154: 887-898.

Chaloupka, M., N. Kamezaki and C. Limpus. - 2008b. Is climate change affecting the population dynamics of the endangered Pacific loggerhead sea turtle? J. Exp. Mar. Biol. Ecol., 356: 136-143.

D'Alba, L., P. Monaghan and R.G. Nager. - 2010. Advances in laying date and increasing population size suggest positive responses to climate change in Common Eiders Somateria mollissima in Iceland. Ibis, 152: 19-28.

Eckert, S.A., J.E. Moore, D.C. Dunn, R.S. van Buiten, K.L. Eckert and P.N. Halpin. - 2008.- Modeling loggerhead turtle movement in the Mediterranean: importance of body size and oceanography. Ecol. Appl., 18: 290-308.

Epperly, S.P., J. Braun, A.J. Chester, F.A Cross, J.V. Merriner, P.A. Tester and J.H. Churchill. - 1996. Beach strandings as an indicator of at-sea mortality of sea turtles. Bull. Mar. Sci., 59(2): 289-297.

Gancedo, U., E. Zorita, A.P. Solari, G. Chust, A.S. del Pino, J. Polanco and J.J. Castro. - 2009. What drove tuna catches between 1525 and 1756 in southern Europe? ICES J. Mar. Sci., 66: 1595-1604.

Goñi, N. and H. Arrizabalaga. - 2005. Analysis of juvenile North Atlantic Albacore (Thunnus alalunga) catch per unit effort by surface gears in relation to environmental variables. ICES $J$. Mar. Sci., 62:1475-1482.

Graham, C.T. and C. Harrold. - 2009. Implications of climate change for the fishes of the British Isles. J. Fish Biol., 74: 1143-1205.

Hawkes, LA, A.C. Broderick, M.S. Coyne, M.H. Godfrey and B.J. Godley. - 2007a. Only some like it hot - quantifying the environmental niche of the loggerhead sea turtle. Diver. Distrib., 13: 447-457.

Hawkes, L.A., A. Broderick, M. Godfrey and B.J. Godley. - 2007b. Investigating the potential impacts of climate change on a marine turtle population. Global Change Biol. . 13: 923-932.

Hurrell, J.W. - 1995. Decadal trends in the North Atlantic Oscillation: Regional temperatures and precipitation. Science, 269: 676-679.

Day, R.D., J.M. Keller, C.A. Harms, A.L. Segars, W.M. Cluse, M.H. Godfrey, A.M. Lee, M. Peden-Adams, K. Thorvalson, M. Dodd and T. Norton. - 2010. comparison of mercury burdens in chronically debilitated and healthy loggerhead sea turtles (Caretta caretta). J. Wildl. Dis., 46(1): 111-117.

Mazaris, A., A. Kallimanis, S. Sgardelis and J. Pantis. - 2008. Do long-term changes in sea surface temperature at the breeding areas affect the breeding dates and reproduction performance of Mediterranean loggerhead turtles? Implications for climate change. J. Exp. Mar. Biol. Ecol., 367: 219-226.

McCallum, M.L., J.L. McCallum and S.E. Trauth. - 2009. Predicted climate change may spark box turtle declines. Amphibia-Reptilia, 30: 259-264

MacLeod, C., G. Pierce and M. Santos. - 2004. Geographic and temporal variations in strandings of beaked whales (Ziphiidae) on the coasts of the UK and the Republic of Ireland from 1800-2002. J. Cetacean Res. Manage., 6: 79-86.

Monzon-Arguello, C., C. Rico, E. Naro-Maciel, N. Varo-Cruz, P. López, A. Marco and L.F. López-Jurado. - 2010. Population structure and conservation implications for the loggerhead sea turtle of the Cape Verde Islands. Conserv. Genet., 11: 1871-1884.

Peng, S., W.A. Robinson and S. Li. - 2002. North Atlantic SST Forcing of the NAO and Relationships with Intrinsic Hemispheric Variability. Geophys. Res. Lett., 29: 1276-1280 DOI10.1029/2001GL014043.

Robinson, A.R., H. Crick, J.A. Learmonth, I.M.D. Maclean, C.D. 
Thomas, F. Bairlein, M.C. Forchhammer, C.M. Francis, J.A. Gill, B.J. Godley, J. Harwood, G.C. Hays, B. Huntley, A.M. Hutson, G.J. Pierce, M.M. Rehfisch, D.W. Sims, M.B. Santos, T.H. Sparks, D.A. Stroud and M.E. Visser. - 2008. Travelling through a warming world: climate change and migratory species. Endang. Species Res. 7: 87-99.

Sánchez, R.F., P. Relvas and M. Delgado. - 2007. Coupled ocean wind and sea surface temperature patterns off the western Iberian Peninsula. J. Mar. Syst., 68: 103-127.

Sims, D.W., M.J. Genner, A.J. Southward, S.J. Hawkins. - 2001. Timing of squid migration reflects North Atlantic climate variability. P. Roy. Soc. B-Biol. Sci., 268: 2607-2611Schofield, G. C.M. Bishop, K.A. Katselidis, P. Dimopoulos, J.D. Pantis and G.C. Hays. - 2009. Microhabitat selection by sea turtles in a dynamic thermal marine environment. J. Anim. Ecol., 78: 14-21.

Tomás, J., P. Gozalbes, J.A. Raga and B.J. Godley. - 2008. Bycatch of loggerhead sea turtles: insights from 14 years of stranding data. Endang. Species Res., 5: 167-169.

Trigo, R.M., D. Pozo-Vázquez, T.J. Osborn, Y. Castro-Díez, S. Gámiz-Fortis and M.J. Esteban-Parra. - 2004. North Atlantic Oscillation influence on precipitation, river flow and water re- sources in the Iberian Peninsula. Int. J. Climatol. 24: 925-944.

Visbeck, M.H., J.W. Hurrell, L. Polvani and H.M. Cullen. - 2001. The North Atlantic Oscillation: Past, present, and future. $P$. Natl. Acad. Sci. USA, 98: 12876-12877.

Watson, J.W., S.P. Epperly, A.K. Shah and D.G. Foster. - 2005. Fishing methods to reduce sea turtle mortality associated with pelagic longlines. Can. J. Fish. Aquat. Sci., 62: 965-981.

Weishampel, J.F., D.A. Bagley and L.M. Ehrhart. - 2004. Earlier nesting by loggerhead sea turtles following surface warming. Global Change Biol., 10: 1-4.

Witt, M.J., R. Penrose and B.J. Godley. - 2007. Spatio-temporal patterns of juvenile marine turtle occurrence in waters of the European continental shelf. Mar. Biol., 151: 873-885.

Witt, M.J., L.A. Hawkes, M.H. Godfrey, B.J. Godley and A.C. Broderick. - 2010. Predicting the impacts of climate change on a globally distributed species: the case of the loggerhead turtle. $J$. Exp. Biol., 213: 901-911.

Scient. ed.: D. Oro.

Received July 29, 2010. Accepted February 4, 2011.

Published online June 3, 2011. 